\title{
The accuracy of Diffusion Weighted Magnetic Resonance Imaging in differentiation of malignant from benign gynecologic lesions
}

\section{Pelvik kitlelerin malign - benign ayırımında Difüzyon Ağırlıklı MRG bulguları}

\author{
Mehtap Balaban $^{1}$, Illkay S İdilman², Ali İpek ${ }^{1}$, Özlem Ünal ${ }^{3}$, Ercan Kocakoç ${ }^{4}$ \\ ${ }^{1}$ Department of Radiology, Ankara Training and Research Hospital, Ankara, Turkey \\ ${ }^{2}$ Department of Radiology, Hacettepe University, Medical Faculty, Ankara, Turkey \\ ${ }^{3}$ Department of Radiology, Yildirim Beyazit University, Medical Faculty, Ankara, Turkey \\ ${ }^{4}$ Department of Radiology, Bahcesehir Medical Park Hospital, İstanbul, Turkey
}

Dergiye Ulașma Tarihi:22.03.2018 Dergiye Kabul Tarihi:27.04.2018 Doi: 10.5505/aot.2018.86548

\section{ÖZET}

GíRISŞ ve AMAÇ: Bu çalışmanın amacı jinekolojik lezyonlarda benign malign ayrımında Difüzyon Ağırlıklı MR incelemenin doğruluğunu araştırmaktır.

YÖNTEM ve GEREÇLER: Çalışmaya pelvik kitle ön tanısıyla alt batın MRG tetkiki istenen toplam 125 olgu dâhil edildi.MR görüntülemeri 1,5 Tesla görüntüleme sisteminde yapıldı. Bu hastalardan DAG ile sırasıyla b100, b600, b1000 gradient değerlerinde difüzyon ağırlıklı EPI görüntüler alındı. Pelvik kitle saptanan olgularda lezyonlardan ADC değerleri ölçüldü, 125 jinekolojik lşezyonda ortalama kitle ADC değerleri karşılaştırıldı.

BULGULAR: Malign lezyon saptanan 35 olgunun lezyona ait ADC değerleri (b100, b600, b1000) (2.18x10-3; $1.47 \times 10-3 ; 1.22 \times 10-3$ ), benign lezyon saptanan 90 olgunun lezyona ait ADC değerlerinden (b100, b600, b1000) (2.60x10-3; 2.05x10-3; 1.79x10-3 mm2/sn) düşük olup aradaki fark istatistiksel olarak anlamlı bulunmuştur $(\mathrm{p}<0,05)$. Ayrıca benign-malign ayrımını yapmamızı sağlayabilecek bir kestirim noktası araştırıldı ve 1.6x10-3 $\mathrm{mm} 2 / \mathrm{s}$ nin b100 değeri için \%40 duyarlllık ve \%88 özgüllük ile; $1.4 \times 10-3 \mathrm{~mm} 2 / \mathrm{s}$ ADC değerinin b600 gradientinde $\% 57$ duyarlılık \%77 özgüllük ile; ve $0.9 \times 10-3 \mathrm{~mm} 2 / \mathrm{s}$ değerinin b1000 gradientinde $\% 57$ duyarlılık ve \%91 özgüllük gösterdiği görüldü. Bu analizler sonucu b1000 ADC değerinin jinekolojik lezyonların benignmalign ayrımında en yüksek doğruluğa sahip olduğu görüldü.

TARTIŞMA ve SONUÇ: ADC değer ölçümleriyle birlikte difüzyon MRG bir fonksiyonel görüntüleme yöntemi olarak kitlelerin malign-benign ayırımında önemli katkılar sağlayabilmektedir.

Anahtar Kelimeler: Manyetik Rezonans Görüntüleme, Pelvik kitle, Difüzyon Ağılıklı Görüntüleme, ADC, Jinekolojik lezyon

\begin{abstract}
INTRODUCTION: The aim of the present study was to investigate the accuracy of diffusion weighted magnetic resonance imaging (DWI) in differentiation of malignant from benign gynecologic lesions. METHODS: A total of 125 patients who underwent pelvic MRI with an initial diagnosis of gynecologic mass included in the study. The MRI examinations were performed on a 1.5 Tesla MR imaging system. The DWI protocol included water excitation with three $\mathrm{b}$ values $(100,600$ and $1000 \mathrm{~s} / \mathrm{mm} 2)$ and apparent diffusion coefficient (ADC) maps were created. Mean ADC values were calculated in 125 gynecologic lesions. RESULTS: We observed significantly lower ADC values in malignant lesions compared with benign ones in all $b$ values ( $p=0.047$ for $b 100, p<0.001$ for $b 600, p<0.001$ for $b 1000$ ). We also evaluated the cut-off points of ADC value for differentiation of malignant from benign lesions and observed $1.6 \times 10-3 \mathrm{~mm} 2 / \mathrm{s}$ for b100 with a sensitivity of $40 \%$ and a specificity of $88 \% ; 1.4 \times 10-3 \mathrm{~mm}^{2} / \mathrm{s}$ for b600 with a sensitivity of $57 \%$ and a specificity of $77 \%$, and $0.9 \times 10-3 \mathrm{~mm}^{2} / \mathrm{s}$ for b1000 with a sensitivity of $57 \%$ and a specificity of $91 \%$. According to these analyses, $\mathrm{ADC}$ value at b1000 was found to have the highest accuracy for differentiation of malignant from benign gynecologic lesions.
\end{abstract}

DISCUSSION and CONCLUSION: ADC measurements can be used for differentiation of malignant from benign gynecologic lesions.

Keywords: Magnetic Resonance Imaging (MRI), Pelvic mass, Diffusion Weighted Imaging (DWI), ADC, Gynecologic lesion 


\section{INTRODUCTION}

Endometrial, cervical and ovarian carcinomas are the most common three gynecologic malignancies of the world. These malignancies are the leading causes of mortality and morbidity in women after breast cancer. Even so, endometrial carcinoma has the highest curability within the most common 10 female malignancies (1). The detection of these malignancies depends on clinical findings and diagnostic imaging methods. The first imaging method for a suspected gynecologic malignancy is ultrasonography which is used to confirm a mass, identify the originating organ and characterize the mass. Despite the useful information accuired with US, magnetic resonance imaging (MRI) is superior because of its soft tissue contrast especially in uterin and cervical lesions (2) and used as a problem solving modality in patients with sonographically undetermined lesions (3).

Conventional MRI has been widely accepted as a valid imaging modality for gynecologic masses. Although the morphologic features of a lesion like solid component or papillary projections for ovarian carcinoma and signal intensity changes for endometrial or cervical carcinoma would be helpful in differentiating a lesion, microstructural changes which would be helpful for characterizing a lesion can not be evaluated with conventional MRI. Diffusion weighted imaging (DWI) is a noninvasive MRI technique which is promising for showing microstructural changes, early tumor detection and evaluation of treatment responce (4). There are numerous studies investigating the accuracy of DWI in differentiating benign lesions from ovarian cancer (5-7), endometrial cancer $(8,9)$, and cervical cancer (10-12). However there is not one study available in the literature which investigates the accuracy of DWI in differentiating malignant from benign lesions which include most of gynecologic lesions. The aim of the present study was to investigate the accuracy of DWI in differentiation of malignant from benign gynecologic masses.

\section{PATIENTS and METHODS}

A total of 125 female patients who referred to our department for pelvic MRI with a suspected gynecologic mass between October 2007 and October 2008 were included in this study. All patients gave written informed consent for MRI examination. This study was approved by our instutitional review board.

From the study patients, 67 were operated and 58 were followed up. According to the histopathologic evaluation and follow up results, the final diagnosis was malignant for 35 lesions and 90 lesions benign. The malignant lesions were endometrial carcinoma in 5 patients $(4 \%)$ cervical carcinoma in 12 patients $(9.6 \%)$ and ovarian carcinoma in 18 patients $(14.4 \%)$. The benign lesions were leiomyom in 28 patients (22.4\%), endometrioma in 12 patients (9.6\%), hemorrhagic ovarian cyst in 12 patients (9.6\%), follicular cyst in 11 patients $(8.8 \%)$, lymphocel in 9 patients $(7.2 \%)$, dermoid tumour in 8 patients $(6.4 \%)$, benign ovarian tumour in 5 patients $(4 \%)$, and nabothi cyst in 5 patients $(4 \%)$ (Table 1$)$.

\section{MR examination}

All patients underwent pelvic MRI with a 1.5 Tesla MR unit (Signa Hispeed Excite General Electric, Milwaukee, WI). The patients were examined in supine position. Diffusionweighted MR images were obtained by a 4channel phased array coil for body, using an echo planar imaging in the axial plane without breath holding in approximately 30 seconds. A three-plane gradient echo localizer sequence was performed at the beginning of the examination. Imaging parameters were repetition time (TR)/ echo time (TE): 8000/80 $\mathrm{ms}$; section thickness: $5 \mathrm{~mm}$; intersection gap: 0 ; matrix size: $128 \times 128$; field of view: $300 \mathrm{x}$ $300 \mathrm{~mm}$, water excitations with $\mathrm{b}$ values of 100, 600 and $1000 \mathrm{~s} / \mathrm{mm}^{2}$ for DWI. Axial T2 weighted spin-echo sequences (TR/TE= 4100/95, section thickness: $5 \mathrm{~mm}$; intersection gap: $1 \mathrm{~mm}$ ) were also performed for lesion detection. T2 weighted images were used for detection of lesion and lesion diameters. Colorcoded ADC maps were automatically created by the diffusion difference between gradients $b$ $100, b 600$ and $b 1000 \mathrm{~s} / \mathrm{mm}^{2}$ and the $b 0$ gradient on a workstation (Advantage Windows, software version 2.0, General Electric Medical Systems). Monoexponential method was used in ADC measurements. A minimum mean square error estimator was 
used in the monoexponential method to minimize the mean square error of the fitted ADC values. The mean ADC values were calculated on images with all acquired $b$ values. A round or elliptical region of interest (ROI) with an area range between $50-70 \mathrm{~mm}^{2}$ was placed by a radiologist (M.B. with 4 years of experience) on color-coded ADC maps of the detected lesions. The ROIs were placed in the centre of pure cystic lesions, the solid component of complex cystic lesions and the markedly diffusion restricted area of degenerate leiomiomas and solid masses (Figure 1).

Lesions were divided into two major groups according to histopathological analyses and follow-up results as malignant lesions and benign lesions. Calculated ADC values for $b$ values of 100,600 and $1000 \mathrm{~s} / \mathrm{mm}^{2}$ were compared for major groups and subgroups.

\section{Statistical analyses}

Data was summarized as mean \pm standard deviation for continuous variables and frequencies for categorical variables. Mann Whitney $\mathrm{U}$ test was used for independent group comparisons depending on the distributional properties of the data. A $p$ value $<0.05$ was considered as statistically significant. In order to determine the diagnostic accuracy of ADC measurements, ROC analysis was performed. Cut-off ranges were calculated around the optimal cut-off to maximize sensitivity and specificity for discrimination of malignant from benign gynecologic lesions. Youden index $\mathrm{J}$ values were used to compare diagnostic accuracy of ADC measeurements in different $b$ values.

\section{RESULTS}

A total of 125 female patients with mean age of 39 (range: 16-75) were included in this study. The final diagnosis was made according to histopathologic evaluation $(n=67)$ or follow up results $(n=58)$. Lesions were divided into two major groups; malignant lesions $(n=35)$ and benign lesions $(n=90)$.

The mean and standard deviation (SD) of $\mathrm{ADC}$ values $\left(\times 10^{-3} \mathrm{~mm}^{2} / \mathrm{s}\right)$ of all lesions were $2.48 \pm 0.9$ for $b 100,1.89 \pm 0.7$ for $b 600$, and $1.63 \pm 0.8$ for $b 1000$. The mean and SD of
ADC values $\left(\times 10^{-3} \mathrm{~mm}^{2} / \mathrm{s}\right)$ of malignant lesions were $2.18 \pm 0.6$ for $b 100,1.48 \pm 0.4$ for $b 600$, and $1.22 \pm 0.2$ for $b 1000$. The mean and SD of ADC values $\left(\times 10^{-3} \mathrm{~mm}^{2} / \mathrm{s}\right)$ of endometrial carcinoma were $1.85 \pm 0.5$ for $b 100,1.16 \pm 0.7$ for $b 600$, and $0.91 \pm 0.1$ for $b 1000$. The mean and SD of ADC values $\left(\times 10^{-3} \mathrm{~mm}^{2} / \mathrm{s}\right)$ of cervical carcinoma were $2.14 \pm 0.6$ for $b 100$, $1.19 \pm 0.4$ for $b 600$, and $0.87 \pm 0.1$ for $b 1000$. The mean and SD of ADC values $\left(\times 10^{-3}\right.$ $\mathrm{mm}^{2} / \mathrm{s}$ ) of ovarian carcinoma were $2.27 \pm 0.6$ for $b 100,1.73 \pm 0.5$ for $b 600$, and $1.51 \pm 0.1$ for $b 1000$.

The mean and SD of ADC values (x10${ }^{3} \mathrm{~mm}^{2} / \mathrm{s}$ ) of benign lesions were $2.60 \pm 0.8$ for $b$ $100,2.05 \pm 0.5$ for $b 600$, and $1.79 \pm 0.2$ for $b$ 1000. The highes ADC values were detected in lymphocels $(3.87 \pm 0.9$ for $b 100,3.05 \pm 0.9$ for $b$ 600 , and $2.86 \pm 0.1$ for $b 1000$ ) and lowest ADC values were detected in endometriomas $(1.84 \pm 0.5$ for $b 100,1.42 \pm 0.3$ for $b 600$, and $1.15 \pm 0.2$ for $b 1000)$. The ADC values of all patients are summarized in Table 1.

The ADC values according to the variable $b$ values were significantly different for malignant and benign masses $(\mathrm{p}<0.001)$ (Figure 2). There were significantly lower ADC values in malignant lesions in all $b$ values ( $\mathrm{p}=0.047$ for $b 100, \mathrm{p}<0.001$ for $b 600$, $\mathrm{p}<0.001$ for $b$ 1000). The cut-off points of $\mathrm{ADC}$ value for differentiation of malignant from benign lesions were $1.6 \times 10^{-3} \mathrm{~mm}^{2} / \mathrm{s}$ for $b$ 100 (area under the curve, 0.615, 95\% confidence interval: $0.524,0.701$, Youden index J: 0.2889) with a sensitivity of $40 \%$ and a specificity of $88 \% ; 1.4 \times 10^{-3} \mathrm{~mm}^{2} / \mathrm{s}$ for $b 600$ (area under the curve, $0.735,95 \%$ confidence interval: 0.649, 0.810, Youden index J: 0.4016) with a sensitivity of $57 \%$ and a specificity of $77 \%$, and $0.9 \times 10^{-3} \mathrm{~mm}^{2} / \mathrm{s}$ for $b 1000$ (area under the curve, 0.752 , 95\% confidence interval: 0.666, 0.824, Youden index J: 0.4825) with a sensitivity of $57 \%$ and a specificity of 91\% (Table 4). According to these analyses, ADC value at $b 1000$ was found to have the highest accuracy for differentiation of malignant from benign gynecologic masses (Table 2, Figure 3). 
Table 1: The details of detected 125 gynecological lesions in 125 patients.

\begin{tabular}{|c|c|c|c|c|}
\hline Final Diagnosis & Numbers & $\begin{array}{c}\text { ADC values } \\
\left(10^{-3} \mathrm{~mm}^{2} / \mathrm{s}\right) \\
b 100 \\
\text { mean }( \pm \mathrm{SD})\end{array}$ & $\begin{array}{c}\text { ADC values } \\
\left(10^{-3} \mathrm{~mm}^{2} / \mathrm{s}\right) \\
b 600 \\
\text { mean }( \pm \mathrm{SD})\end{array}$ & $\begin{array}{c}\text { ADC values } \\
\left(10^{-3} \mathrm{~mm}^{2} / \mathrm{s}\right) \\
b 1000 \\
\text { mean }( \pm \mathrm{SD})\end{array}$ \\
\hline $\begin{array}{l}\text { Benign Gynecologic } \\
\text { Lesions }\end{array}$ & 90 & $2.60( \pm 0.8)$ & $2.05( \pm 0.5)$ & $1.79( \pm 0.2)$ \\
\hline $\begin{array}{l}\text { Benign ovarian } \\
\text { tumour }\end{array}$ & 5 & $2.84( \pm 0.6)$ & $2.54( \pm 0.6)$ & $2.41( \pm 0.3)$ \\
\hline Endometrioma & 12 & $1.84( \pm 0.5)$ & $1.42( \pm 0.3)$ & $1.15( \pm 0.2)$ \\
\hline Ovarian dermoid & 8 & $2.35( \pm 0.5)$ & $1.72( \pm 0.4)$ & $1.52( \pm 0.2)$ \\
\hline Follicular cyst & 11 & $3.39( \pm 0.9)$ & $2.72( \pm 0.8)$ & $2.45( \pm 0.1)$ \\
\hline Hemorrhagic cyst & 12 & $2.70( \pm 0.7)$ & $2.32( \pm 0.6)$ & $2.10( \pm 0.1)$ \\
\hline Lymphocele & 9 & $3.87( \pm 0.9)$ & $3.05( \pm 0.9)$ & $2.86( \pm 0.1)$ \\
\hline Leiomyoma & 20 & $2.15( \pm 0.6)$ & $1.53( \pm 0.5)$ & $1.22( \pm 0.1)$ \\
\hline $\begin{array}{l}\text { Degenerating } \\
\text { Leiomyoma }\end{array}$ & 8 & $1.94( \pm 0.5)$ & $1.59( \pm 0.3)$ & $1.10( \pm 0.1)$ \\
\hline Nabothian Cyst & 5 & $2.74( \pm 0.7)$ & $2.03( \pm 0.5)$ & $1.93( \pm 0.1)$ \\
\hline $\begin{array}{l}\text { Malignant } \\
\text { Gynecologic Lesions }\end{array}$ & 35 & $2.18( \pm 0.6)$ & $1.48( \pm 0.4)$ & $1.22( \pm 0.2)$ \\
\hline $\begin{array}{l}\text { Endometrial } \\
\text { Carcinoma }\end{array}$ & 5 & $1.85( \pm 0.5)$ & $1.16( \pm 0.7)$ & $0.91( \pm 0.1)$ \\
\hline Cervical carcinoma & 12 & $2.14( \pm 0.6)$ & $1.19( \pm 0.4)$ & $0.87( \pm 0.1)$ \\
\hline Ovarian carcinoma & 18 & $2.27( \pm 0.6)$ & $1.73( \pm 0.5)$ & $1.51( \pm 0.1)$ \\
\hline
\end{tabular}

Table 2 Diagnostic accuracy of ADC measurement for estimation of malignant lesions

\begin{tabular}{|c|c|c|c|c|c|c|}
\hline $\begin{array}{l}\text { Patients } \\
\text { Cut-off value }\end{array}$ & $\mathbf{A U C}$ & $\begin{array}{l}\text { Sensitivity } \\
(95 \% \text { CI })\end{array}$ & $\begin{array}{l}\text { Specificity } \\
(95 \% \text { CI })\end{array}$ & $\begin{array}{c}\text { PPV } \\
(95 \% \text { CI })\end{array}$ & $\begin{array}{c}\text { NPV } \\
(95 \% \mathrm{CI}) \\
\end{array}$ & p value \\
\hline $\begin{array}{l}b 100 \leq 1.6 \times 10^{-} \\
{ }^{3} \mathrm{~s} / \mathrm{mm}^{2}\end{array}$ & $\begin{array}{c}0.615 \\
(0.524-0.701)\end{array}$ & $\begin{array}{c}0.40 \\
(0.24,0.58)\end{array}$ & $\begin{array}{c}0.88 \\
(0.80,0.94)\end{array}$ & $\begin{array}{c}0.58 \\
(0.37,0.78)\end{array}$ & $\begin{array}{c}0.79 \\
(0.70,0.87)\end{array}$ & 0.070 \\
\hline $\begin{array}{l}\mathbf{b 6 0 0} \\
\leq 1.4 \times 10^{-3} \\
\mathrm{~s} / \mathrm{mm}^{2}\end{array}$ & $\begin{array}{c}0.735 \\
(0.649-0.810)\end{array}$ & $\begin{array}{c}0.57 \\
(0.39,0.74)\end{array}$ & $\begin{array}{c}0.77 \\
(0.67,0.85)\end{array}$ & $\begin{array}{c}0.49 \\
(0.33,0.65)\end{array}$ & $\begin{array}{c}0.82 \\
(0.72,0.90)\end{array}$ & $<0.001$ \\
\hline $\begin{array}{l}\text { b1000 } \\
\leq 0.9 \times 10^{-3} \\
\mathrm{~s} / \mathrm{mm}^{2}\end{array}$ & $\begin{array}{c}0.752 \\
(0.666-0.824\end{array}$ & $\begin{array}{c}0.57 \\
(0.39,0.74)\end{array}$ & $\begin{array}{c}0.91 \\
(0.83,0.96)\end{array}$ & $\begin{array}{c}0.71 \\
(0.51,0.87)\end{array}$ & $\begin{array}{c}0.85 \\
(0.76,0.91)\end{array}$ & $<0.001$ \\
\hline
\end{tabular}

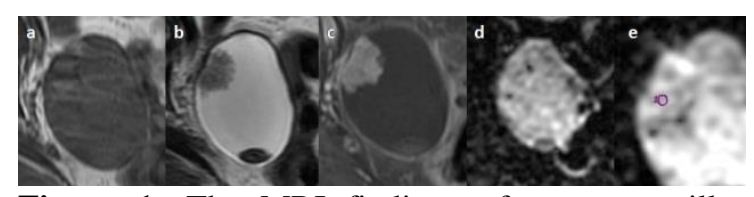

Figure 1: The MRI findings of serous papiller ovarian carcinoma in right ovary with irregular shaped solid component. The features of $\mathrm{T} 1$ weighted imaging (a), T2 weighted imaging (b), postcontrast fat saturation T1 weighted imaging (c), and diffusion restriction on DWI is seen. The measurement from solid component on ADC map reveals an ADC value of $0.67 \times 10^{-3} \mathrm{~mm}^{2} / \mathrm{s}(\mathrm{e})$.

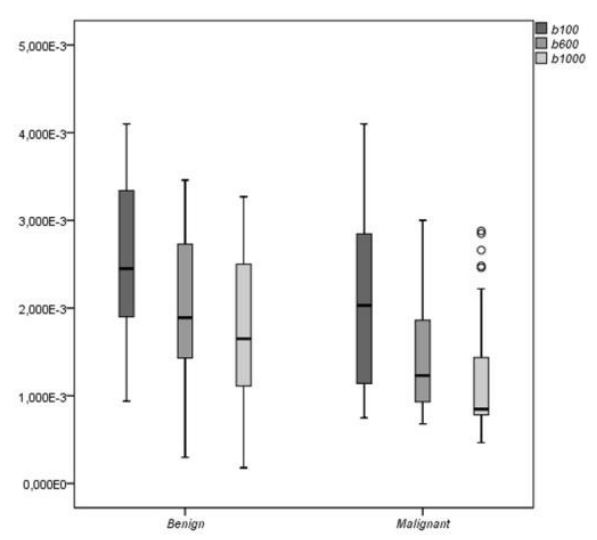

Figure 2: Box plot shows the different ADC values according to $b 100, b 600$ and $b 1000$ between malignant and benign gynecologic lesions. 


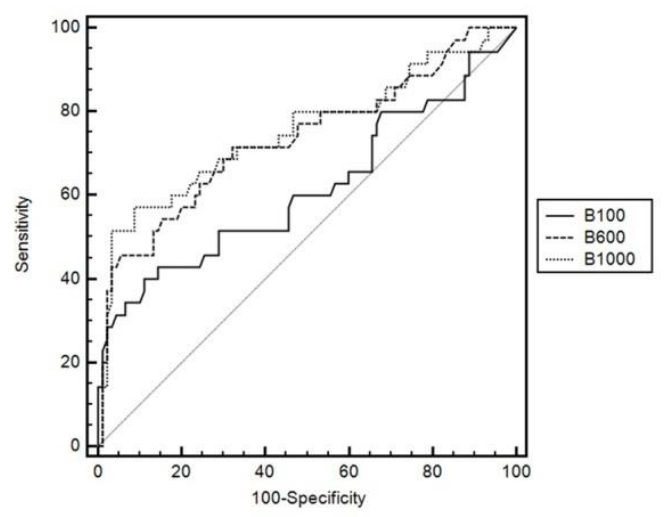

Figure 3: Graph shows ROC curve for discriminating malignant from benign gynecologic lesions.

\section{DISCUSSION}

Decreased ADC values have been reported in various malignities which can be explained by the increased cellular density of tissue (13-15). There are also various MRI studies which evaluate the accuracy of DWI in differentiation of specific gynecologic malignities like endometrial, cervical and ovarian carcinomas from benign lesions or other conditions. Tamai et al observed significantly lower mean ADC values in patients with endometrium carcinoma as compared with normal endometrium $(0.88 \pm$ 0.16 vs $1.53 \pm 0.10 \times 10^{-3} \mathrm{~mm}^{2} / \mathrm{s}$ ). Another study by Fuji et al observed lower ADC values in endometrial carcinoma $\left(0.98 \pm 0.21 \times 10^{-3}\right.$ $\left.\mathrm{mm}^{2} / \mathrm{s}\right)$ and carcinosarcoma $\left(0.97 \pm 0.02 \times 10^{-3}\right.$ $\mathrm{mm}^{2} / \mathrm{s}$ ) compared with submucosal leiomyoma $\left(1.37 \pm 0.28 \times 10^{-3} \mathrm{~mm}^{2} / \mathrm{s}\right)$ and endometrial polyp $\left(1.58 \pm 0.45 \times 10^{-3} \mathrm{~mm}^{2} / \mathrm{s}\right)$. They also showed a cut off value for differentiation of malignant from benign lesions as $1.15 \times 10^{-3}$ $\mathrm{mm}^{2} / \mathrm{s}$ with a sensitivity of $84.6 \%$ and specificity of $100 \%$. In the present study we observed ADC values for endometrial carcinoma as $1.85 \times 10^{-3} \mathrm{~mm}^{2} / \mathrm{s}$ for $b 100,1.16$ $\times 10^{-3} \mathrm{~mm}^{2} / \mathrm{s}$ for $b 600$, and $0.91 \times 10^{-3} \mathrm{~mm}^{2} / \mathrm{s}$ for $b 1000$.

Naganawa et al. observed lower ADC values in cervical cancer lesions compared with normal cervical tissue $\left(1.09 \pm 0.20 \times 10^{-3}\right.$ $\mathrm{mm}^{2} / \mathrm{s}$, vs, $\left.1.79 \pm 0.24 \times 10^{-3} \mathrm{~mm}^{2} / \mathrm{s}, \mathrm{p}<0.0001\right)$ (10). Similarly, Chen et al. observed lower ADC values in cervical carcinoma compared with normal cervical tissue $\left(1.110 \pm 0.175 \times 10^{-}\right.$ ${ }^{3} \mathrm{~mm}^{2} / \mathrm{s}$, vs, $1.593 \pm 0.151 \times 10^{-3} \mathrm{~mm}^{2} / \mathrm{s}$, $\mathrm{p}<0.001)$ (11). The study by Mcveigh et al. showed lower ADC values in cervical carcinomas compared with normal cervix (1.09 $\pm 0.20 \times 10^{-3} \mathrm{~mm}^{2} / \mathrm{s}$, vs, $2.09 \pm 0.46 \times 10^{-3}$ $\left.\mathrm{mm}^{2} / \mathrm{s}, \mathrm{p}<0.001\right)(12)$. In the present study, we observed ADC values for cervical carcinoma as $2.14 \times 10^{-3} \mathrm{~mm}^{2} / \mathrm{s}$ for $b 100,1.18 \times 10^{-3} \mathrm{~mm}^{2} / \mathrm{s}$ for $b 600$ and $0.86 \times 10^{-3} \mathrm{~mm}^{2} / \mathrm{s}$ for $b 1000$.

There are various studies that investigate the value of DWI in differentiating ovarian lesion in the literature. Nakayama et al. observed lower ADC values in mature cystic teratomas compared with other benign and malignant ovarian cystic masses $(\mathrm{p}<0.005)$ (16). Moteki et al. observed lower ADC values in endometrial cyst and malignant ovarian tumors compared with ovarian cyst, serous cystadenomas and mucinous cystadenomas $(\mathrm{p}<0.02)(17)$. Another study by Moteki et al. showed lower ADC values in cystic contents of endometrial cysts and malignant cystic ovarian tumors compared with ovarian cysts and serous cystadenomas $(p<0.003)$ (18). Bakır et al. investigated the usefulness of DWI in solid or predominantly solid adnexial and ovarian lesions, and observed no significant difference between malignant and benign masses' ADC values (5). Zhang et al. observed a significantly lower mean ADC value of the solid component of malignant tumors compared with benign tumors $(\mathrm{p}<0.05)(6)$. Another study by Zhang et al. observed lower ADC values in malignant adnexial tumors compared with benign ones $(\mathrm{p}=0.000)(7)$.

A study by Namimoto et al. reviewed the role of DWI in the diagnosis of gynecological diseases and concluded that ADC can help to differentiate malignant from normal tissue in the uterin cervix and endometrium (19). They also added the utility of this technique is limited in uterine myometrium and ovaries. In the present study we evaluated the accuracy of DWI in differentiation of malignant versus benign gynecologic lesions. We observed significantly lower ADC values in malignant lesions in all $b$ values ( $\mathrm{p}=0.047$ for $b 100, \mathrm{p}<0.001$ for $b 600$, $\mathrm{p}<0.001$ for $b$ 1000). We also evaluated the cut-off points of ADC value for the differentiation of malignant from benign lesions and observed $1.6 \times 10^{-3} \mathrm{~mm}^{2} / \mathrm{s}$ for $b 100$ with a sensitivity of $40 \%$ and a specificity of $88 \% ; 1.4 \times 10^{-3} \mathrm{~mm}^{2} / \mathrm{s}$ for $b 600$ with a 
sensitivity of $57 \%$ and a specificity of $77 \%$, and $0.9 \times 10^{-3} \mathrm{~mm}^{2} / \mathrm{s}$ for $b 1000$ with a sensitivity of $57 \%$ and a specificity of $91 \%$. According to these analyses, ADC value at $b$ 1000 was found to have the highest accuracy for differentiation of malignant from benign gynecologic masses.

There are some limitations in this study. The total cohort has a sufficient sample size; however, subgroup size is quite small. The lesions included in this study have heterogeneity such as being cystic or solid. However, our purpose was to differentiate malignant lesions from benign ones, independent of lesions' nature and other imaging findings.

In conclusion, we observed significantly lower ADC values in gynecologic malignant lesions in all $b$ values with the highest accuracy for ADC value at $b 1000$. According to our study, ADC measurements can be used for differentiation of malignant from benign gynecologic lesions.

Conflict of interest: The authors declare that they have no conflict of interest

\section{REFERENCES}

1. Rose PG. Endometrial carcinoma. N Eng J Med 1996; 335: 640-649.

2. Balan P.Ultrasonography, computed tomography and magnetic resonance imaging in the assesment of pelvic pathology. Eur J Radiol 2006; 58(1): 14755 .

3. Spencer JA, Ghattamaneni S. MR imaging of the sonographically indeterminate adnexal mass. Radiology 2010; 256: 677-694.

4. Thoeny HC, Ross BD. Predicting and monitoring cancer treatment response with diffusion-weighted MRI. J Magn Reson Imaging 2010; 32: 2-16.

5. Bakır B, Bakan $S$, Tunacı $M$, Bakır VL, Iyibozkurt AC, Berkman S, Bengisu E, Salmaslioglu A. Diffusion-weighted imaging of solid or predominantly solid gynecologic adnexal masses: is it useful in the differential diagnosis? Br J Radiol 2011; 84: 600-611.

6. Zhang P, Cui Y, Li W, Ren G, Chu C, Wu X. Diagnostic accuracy of diffusion-weighted imaging with conventional MR imaging for differentiating complex solid and cystic ovarian tumors at $1.5 \mathrm{~T}$. World J Surg Oncol 2012; 10: 237.

7. Zhang H, Zhang GF, He ZY, Li ZY, Zhu M, Zhang GX. Evaluation of primary adnexal masses by $3 \mathrm{~T}$ MRI: categorization with conventional MR imaging and diffusion-weighted imaging. J Ovarian Res. 2012; 5: 33 .
8. Fujii S, Matsusue E, Kigawa J, Sato S, Kanasaki Y, Nakanishi J, Sugihara S, Kaminou T, Terakawa N, Ogawa T. Diagnostic accuracy of the apparent diffusion coefficient in differentiating benign from malignant uterine endometrial cavity lesions: initial results. Eur Radiol 2008; 18: 384-389.

9. Tamai K, Koyama T, Saga T, Umeoka S, Mikami Y, Fujii S, Togashi K. Diffusion-weighted MR imaging of uterine endometrial cancer. J Magn Reson Imaging. 2007; 26: 682-687.

10. Naganawa $S$, Sato $C$, Kumada $H$, Ishigaki $T$, Miura S, Takizawa O. Apparent diffusion coefficient in cervical cancer of the uterus: comparison with the normal uterin cervix. Eur Radiol 2005; 15: 71-78.

11. Chen J, Zhang Y, Liang B, Yang Z. The utility of diffusion-weighted MR imaging in cervical cancer. Eur J Radiol 2010; 74: e101-e106.

12. McVeigh PZ, AM, Milosevic M, Fyles A, Haider MA. Diffusion-weighted MRI in cervical cancer. Eur Radiol 2008; 18: 1058-1064.

13. Anderson AW, Xie J, Pizzonia J, Bronen RA, Spencer DD, Gore JC. Effects of cell volume fraction changes on apparent diffusion in human cells. Magn Reson Imaging 2000; 18: 689-695.

14. Hein PA, Kremser C, Judmaier W, Griebel J, Pfeiffer KP, Kreczy A, et al. Diffusion-weighted magnetic resonance imaging for monitoring diffusion changes in rectal carcinoma during combined, preoperative chemoradiation: preliminary results of a prospective study. Eur $\mathbf{J}$ Radiol 2003; 45: 214-222.

15. Hein PA, Eskey CJ, Dunn JF, Hug EB. Diffusionweighted imaging in the follow-up of treated high-grade gliomas: tumor recurrence versus radiation injury. Am J Neuroradiol 2004; 25: 201 109.

16. Nakayama $T$, Yoshimitsu $K$, Irie $H$, Aibe $H$, Tajima T,Nishie A, et al. Diffusion-weighted echo-planar MR imaging and ADC mapping in the differential diagnosis of ovarian cystic masses: usefulness of detecting keratinoid substances in mature cystic teratomas. J Magn Reson Imaging 2005; 22: 271-278.

17. Moteki $\mathrm{T}$, Ishızaka $\mathrm{H}$. Evaluation of cystic ovarian lesions using apparent diffusion coefficent calculated from reordered turboflash MR images. Magn Reson Imaging 1999; 7: 955963.

18. Moteki T, Ishızaka H. Diffusion-weighted EPI of cystic ovarian lesions: evaluation of cystic contents using apparent diffusion coefficients. J Magn Reson Imaging 2000; 12: 1014-1019.

Namimoto T, Awai K, Nakaura T, Yanaga Y, Hirai T, Yamashita Y. Role of diffusion-weighted imaging in the diagnosis of gynecological diseases. Eur Radiol 2008; 10: 1185-1195. 